Original article

\title{
Experimental studies of the effect of sea buckthorn and wheat bran in food on the physiological status of rats
}

\author{
Olga S. Fomenko ${ }^{1}$, Anastasiya N. Makarova ${ }^{1}$, Inna V. Simakova ${ }^{1}$, Yuriy Yu. Eliseev ${ }^{2}$, Yuliya V. Eliseeva ${ }^{2}$, Elena N. \\ Artemova $^{3}$
}

${ }^{1}$ Saratov State Agrarian University, Saratov, Russia

${ }^{2}$ Saratov State Medical University, Saratov, Russia

${ }^{3}$ Orel state University, Orel, Russia

Received 15 April 2018, Revised 10 August 2020, Accepted 24 August 2020

(C) 2018, Fomenko O.S., Makarova A.N., Simakova I.V., Eliseev Yu.Yu., Eliseeva Yu.V., Artemova E.N.

(C) 2018, Russian Open Medical Journal

Abstract: The aim of this research paper was a sanitary-toxicological study of the effectiveness and safety of developed functional property products, such as chopped semi-finished products from chicken with wheat bran and shortbread cake with cottage cheese and sea buckthorn, in preclinical studies on laboratory animals.

Methods - The effect of new products on the experimental rats was studied using physiological, biochemical, pathomorphological and histological research methods. As a result, it was discovered that the inclusion of foods with wheat bran and fresh sea buckthorn into the diet of experimental animals had a positive effect on the behavioral reactions of rats, the increase of appetite and the rapid growth of animals.

Results - The improvement in the metabolic processes physiology of the studied rats was noted in the biochemical and morphological blood parameters. In the experimental group of rats where carbohydrates were partially substituted with cottage cheese shortbread cake and sea buckthorn, a significant decrease in the total bilirubin content was noted; the level of cholesterol in the blood serum of experimental animals from group which received chicken cutlets with bran was 1.4-1.7 times lower than the cholesterol content in animals of the control and other experimental groups. At the same time, statistically significant differences in the number of red blood cells, white blood cells, platelets and hemoglobin level, the activity of alanine and aspartate aminotransferases, alkaline phosphatase and amylase, the level of total protein and the creatinine content were not revealed in the group of experimental rats compared with the control group of rats, receiving a standard diet. The histological data showed that the liver structure of the experimental animals had a more pronounced beam and capillary structure compared with the control group, and the condition of the villi and epithelium of the small intestine showed the positive physiological effect of the studied herbal additives in food technology with functional properties.

Conclusion - The research results allow us to conclude that the developed products are functional, intended for the systematic use in the composition of food rations by all age groups of a healthy population, which reduces the risk of gastrointestinal and liver diseases.

Keywords: shortbread cake with cottage cheese, chicken cutlets, sea buckthorn, wheat bran, physio-logical effect, safety.

Cite as Fomenko OS, Makarova AN, Simakova IV, Eliseev YuYu, Eliseeva YuV, Artemova EN. Experimental studies of the effect of sea buckthorn and wheat bran in food on the physiological status of rats. Russian Open Medical Journal 2020; 9: e0304.

Correspondence to Olga S. Fomenko. Address: Department of Food Technology, Saratov State Agrarian University, Saratov, Teatralnaya sq., 1, Russia. Phone:+79063178981. E-mail: fomenkoos@mail.ru.

\section{Introduction}

In recent years, there has been a clear trend towards an increase in nutrition dependent diseases, characterized by the use of a large number of refined foods and low consumption of essential substances, without which the proper functioning of the body is impossible. Fighting nutrition dependent diseases, the socalled "diseases of civilization", is possible only by including foods enriched with functional ingredients with a pronounced physiological effect in the diet.

Currently, the relevant direction of scientific research is the creation of food products with biologically active substances that have a certain physiological effect. Moreover, the enrichment of food products of various kinds with functional ingredients should be carried out only scientifically, by studying the mechanisms of their therapeutic and prophylactic effect on the body. The inclusion of fresh sea buckthorn in the traditional recipe for shortbread cake with cottage cheese and wheat bran in a similar recipe for chicken cutlets was reasonable [1-3].

Wheat bran is a powerful source of dietary fiber which is about $43.6 \%$. On average, wheat bran contains $15.1 \%$ of protein, $3.8 \%$ of fat, $53.8 \%$ of carbohydrates and $8.2 \%$ of fiber. Their mineral composition includes potassium, magnesium, chromium, zinc, copper and other micronutrients, vitamins $\mathrm{B}, \mathrm{PP}, \mathrm{C}$, provitamin $\mathrm{A}$ and $E$, as well as selenium. The consumption of bran, as a source of dietary fiber, has a beneficial effect on the biological processes 
taking place in the human body. Due to ion-exchange and adsorption properties, they bind and excrete many harmful substances from the body: nitrates, nitrites, formaldehydes, phenols, pesticides, heavy metals, mycotoxins, which contribute to the detoxification of the body $[4,5]$.

The choice of sea buckthorn is due to its taste and functionaltechnological properties. Fresh sea buckthorn contains polyunsaturated essential fatty acids, ascorbic acid, carotenoids, thiamine, niacin, riboflavin, tocopherol, lycopene, folic acid, phylloquinone, sugars, tannins.

The consumption of sea buckthorn has a positive effect in the treatment of cardiovascular system and blood diseases, gastritis, peptic ulcer and duodenum, lack of vitamins, as a prophylactic to reduce degenerative processes of changes in the mucous membrane of the esophagus. In general, sea buckthorn is a product that has a lipotropic, antioxidant, immunostimulating effect [6-9]. However, research works on sea buckthorn as a carrier of physiologically functional ingredients used to create products with functional properties based on it, are not represented enough in evidence-based medicine.

The purpose of the paper was to study the effect of sea buckthorn on the physiological efficiency of shortbread cake with cottage cheese and the effect of wheat bran on chicken cutlets in vivo.

\section{Material and Methods}

\section{Research food}

The authors have developed the recipes and production technologies for the following types of products: chicken cutlets using wheat bran $[10,12]$, shortbread cake with cottage cheese and sea buckthorn $[11,13]$.

As control products, traditional recipes were used for: shortbread cake with cottage cheese, chicken cutlets.

The inclusion of fresh sea buckthorn and wheat bran into the recipes made it possible to obtain products with higher taste characteristics as well as functional and technological properties. Nutrition, energy value, mineral and vitamin composition per 100 $\mathrm{g}$ of developed products are presented in Table 1.

The developed products practically do not differ from the control samples prepared according to traditional recipes in terms of the content of basic nutrients and energy value. However, the inclusion of fresh sea buckthorn fruits allowed enriching the cake with provitamin A and riboflavin, significantly increasing the content of ascarboxylic acid, and increasing the tocopherol equivalent (TE). It, thus, increases the antioxidant activity necessary to stabilize the fat component of the product and prevent oxidative processes.

Table 1. Analysis of the nutritional and energy value of foods

\begin{tabular}{|c|c|c|c|c|}
\hline \multirow[b]{2}{*}{ Parameters } & \multicolumn{4}{|c|}{ Food items } \\
\hline & $\begin{array}{c}\text { Shortbread cake with } \\
\text { cottage cheese }\end{array}$ & $\begin{array}{l}\text { Shortbread cake with cottage } \\
\text { cheese and sea buckthorn }\end{array}$ & chicken cutlets & $\begin{array}{c}\text { chicken cutlets with } \\
\text { bran }\end{array}$ \\
\hline Water, g. & 34.73 & 35.60 & 61.68 & 62.02 \\
\hline Proteins, g. & 9.08 & 9.09 & 12.37 & 12.62 \\
\hline Fats, $g$ & 19.70 & 18.98 & 9.28 & 9.40 \\
\hline Unsaturated fatty acids (UFA), g. & 11.66 & 11.19 & 2.34 & 2.36 \\
\hline Polyunsaturated fatty acids (PUFA), g. & 0.40 & 0.36 & - & - \\
\hline Cholesterol, mg. & 54.20 & 52.50 & 39.24 & 39.24 \\
\hline Mono- and disaccharides (MDS). g. & 34.20 & 33.89 & 0.25 & 0.45 \\
\hline Starch, g. & 19.60 & 19.60 & 10.72 & 7.96 \\
\hline Carbohydrates, g. & 54.02 & 53.79 & 10.99 & 8.43 \\
\hline Dietary fiber (DF), g. & 1.00 & 1.03 & 1.46 & 3.35 \\
\hline Organic acids (OA), g. & 0.31 & 0.34 & 0.18 & 0.16 \\
\hline Ash, g. & 0.70 & 0.71 & 0.93 & 1.06 \\
\hline Energy value, kcal. & 421.53 & 414.33 & 189.93 & 187.90 \\
\hline \multicolumn{5}{|c|}{ Mineral elements } \\
\hline Sodium, mg & 36.43 & 36.40 & 147.93 & 143.55 \\
\hline Potassium, mg. & 148.99 & 151.38 & 141.45 & 155.00 \\
\hline Calcium mg & 68.50 & 68.59 & 15.85 & 17.00 \\
\hline Magnesium, mg. & 40.78 & 41.18 & 21.91 & 24.77 \\
\hline Phosphorus, mg. & 116.00 & 116.02 & 150.76 & 159.22 \\
\hline Iron, mg. & 0.99 & 1.01 & 1.64 & 1.91 \\
\hline \multicolumn{5}{|c|}{ Vitamins } \\
\hline Retinol, mcg. & 158.70 & 152.80 & 39.24 & 39.24 \\
\hline B-carotene, mg. & 84.00 & 100.00 & 5.99 & 6.23 \\
\hline Retinol equivalent (RE), mg & 172.21 & 169.51 & 40.44 & 40.49 \\
\hline Tocopherol equivalent (TE), mg & 1.32 & 1.36 & 0.68 & 0.72 \\
\hline Thiamine, mg & 0.07 & 0.0704 & 0.08 & 0.08 \\
\hline Riboflavin, mg. & - & 0.181 & 0.09 & 0.10 \\
\hline Nicotinic acid, mg & - & 0.003 & - & - \\
\hline Pyridoxine, mg. & - & 0.01 & - & - \\
\hline Folic acid, mg. & - & 0.12 & - & - \\
\hline Biotin, mg & - & 0.043 & - & - \\
\hline Niacin, mg & 0.46 & 0.47 & 4.78 & 4.78 \\
\hline Niacin equivalent, mg. & 2.48 & 2.49 & 7.82 & 24.33 \\
\hline Ascorbic acid, mg. & 0.12 & 2.72 & 1.00 & 1.00 \\
\hline
\end{tabular}


Table 2. The daily diet of the control and experimental groups of laboratory animals No. 1 and 2: en-ergy value, the content of macro- and micronutrients

\begin{tabular}{|c|c|c|c|c|c|c|c|c|c|}
\hline \multirow[b]{2}{*}{ Parameters } & \multirow{2}{*}{$\begin{array}{c}\text { Net weight, } \\
g\end{array}$} & \multirow{2}{*}{$\begin{array}{l}\text { Proteins, } \\
\quad g\end{array}$} & \multirow{2}{*}{$\begin{array}{l}\text { Fats, } \\
\quad g\end{array}$} & \multirow{2}{*}{$\begin{array}{l}\text { Carbohydrates, } \\
\qquad g\end{array}$} & \multirow{2}{*}{$\begin{array}{l}\text { Energy value, } \\
\text { kcal }\end{array}$} & \multicolumn{4}{|c|}{ Vitamins, $m g$} \\
\hline & & & & & & B-carotene & Riboflavin & $\begin{array}{c}\text { Tocopherol } \\
\text { equivalent (TE) }\end{array}$ & Ascorbic acid \\
\hline Cereal mix & 15.00 & 2.88 & 5.73 & 4.65 & 79.05 & 0.001 & 0.010 & 0.740 & 0.05 \\
\hline Bread & 4.00 & 0.30 & 0.04 & 1.87 & 8.54 & - & 0.002 & 0.040 & - \\
\hline Oat groats & 3.00 & 0.37 & 0.18 & 1.78 & 10.26 & - & 0.003 & 0.050 & - \\
\hline Milk & 8.00 & 0.23 & 0.27 & 0.38 & 4.80 & 0.001 & 0.012 & - & 0.10 \\
\hline Meat & 5.00 & 1.01 & 0.14 & - & 5.30 & - & 0.013 & 0.030 & - \\
\hline Juicy food, greens & 20.00 & 0.16 & 0.02 & 0.50 & 2.80 & 0.012 & 0.008 & 0.020 & 2.00 \\
\hline Fish oil & 0.10 & - & 0.10 & - & 0.90 & - & - & - & - \\
\hline Meat and fish meal & 0.70 & 0.47 & 0.06 & - & - & - & - & - & - \\
\hline Feed yeast & 0.20 & 0.03 & 0.01 & 0.02 & 0.22 & - & 0.001 & 0.002 & - \\
\hline Salt & 0.20 & - & - & - & - & - & - & - & - \\
\hline Shortbread cake with cottage cheese & 7.00 & 0.64 & 1.38 & 3.78 & 29.50 & 5.88 & - & 0.090 & 0.01 \\
\hline $\begin{array}{l}\text { Shortbread cake with cottage cheese and } \\
\text { sea buckthorn }\end{array}$ & 7.00 & 0.64 & 1.33 & 3.77 & 29.00 & 7.00 & 0.013 & 0.100 & 0.19 \\
\hline \multicolumn{10}{|l|}{ Total: } \\
\hline In a standard diet & & 5.45 & 6.54 & 9.20 & 111.87 & 0.014 & 0.039 & 0.882 & 2.12 \\
\hline $\begin{array}{l}\text { In the diet No. } 1 \text { with a shortbread cake } \\
\text { with cottage cheese }\end{array}$ & & 5.42 & 7.71 & 9.33 & 122.57 & 5.90 & 0.039 & 0.882 & 2.13 \\
\hline $\begin{array}{l}\text { In the diet No. } 2 \text { with a shortbread cake } \\
\text { with cottage cheese and sea buckthorn }\end{array}$ & & 5.42 & 7.66 & 9.32 & 122.07 & 7.02 & 0.052 & 0.892 & 2.31 \\
\hline
\end{tabular}

Table 3. The daily diet of the control and experimental groups of laboratory animals No. 3, 4: energy value, the content of macro- and micronutrients

\begin{tabular}{|c|c|c|c|c|c|c|c|c|c|c|}
\hline \multirow{2}{*}{ Parameters } & \multirow{2}{*}{$\begin{array}{c}\text { Net } \\
\text { weight, } g\end{array}$} & \multirow{2}{*}{$\begin{array}{l}\text { Proteins, } \\
g\end{array}$} & \multirow{2}{*}{$\begin{array}{c}\text { Fats, } \\
g\end{array}$} & \multirow{2}{*}{$\begin{array}{c}\text { Carbohydrates, } \\
g\end{array}$} & \multirow{2}{*}{$\begin{array}{c}\text { Energy } \\
\text { value, } \mathrm{kcal}\end{array}$} & \multirow{2}{*}{$\begin{array}{c}\text { Dietary } \\
\text { fiber }(D F)\end{array}$} & \multirow{2}{*}{$\begin{array}{c}\text { Vitamins, } g \\
\text { PP }\end{array}$} & \multicolumn{3}{|c|}{ Mineral elements, $\mathrm{mg}$} \\
\hline & & & & & & & & $\mathrm{Fe}$ & $\mathrm{Mg}$ & $\mathrm{Ca}$ \\
\hline Cereal mix & 15.00 & 2.88 & 5.73 & 4.65 & 79.05 & 2.53 & 0.95 & 0.75 & 48.55 & 33.85 \\
\hline Bread & 4.00 & 0.30 & 0.04 & 1.87 & 8.54 & - & 0.11 & 0.08 & 1.32 & 0.92 \\
\hline Oat groats & 3.00 & 0.37 & 0.18 & 1.78 & 10.26 & 0.24 & 0.13 & 0.12 & 3.48 & 1.92 \\
\hline Milk & 8.00 & 0.23 & 0.26 & 0.38 & 4.80 & - & 0.06 & 0.01 & 1.12 & 9.60 \\
\hline Meat & 5.00 & 1.01 & 0.14 & - & 5.30 & - & 0.29 & 0.13 & 1.35 & 0.50 \\
\hline Juicy food, greens & 20.00 & 0.16 & 0.02 & 0.50 & 2.80 & 0.20 & 0.06 & 0.12 & 2.80 & 4.60 \\
\hline Fish oil & 0.10 & - & 0.10 & - & 0.90 & - & - & - & - & - \\
\hline Meat and fish meal & 0.70 & 0.47 & 0.06 & - & - & - & - & - & - & - \\
\hline Feed yeast & 0.20 & 0.03 & 0.01 & 0.02 & 0.22 & - & 0.03 & 0.01 & 0.10 & 0.05 \\
\hline Salt & 0.20 & - & - & - & - & - & - & 0.01 & 0.04 & 0.74 \\
\hline Chicken cutlets & 10 & 1.24 & 0.93 & 1.10 & 18.99 & 0.15 & 0.78 & 0.16 & 2.19 & 1.58 \\
\hline Chicken cutlets with bran & 10 & 1.26 & 0.94 & 0.84 & 18.79 & 0.34 & 2.43 & 0.19 & 2.48 & 1.70 \\
\hline \multicolumn{11}{|l|}{ Total: } \\
\hline in a standard diet & & 5.45 & 6.54 & 9.20 & 111.87 & 2.97 & 1.63 & 1.22 & 58.76 & 52.18 \\
\hline In the diet No. 3 with chicken cutlets & & 5.21 & 7.27 & 10.30 & 125.56 & 3.12 & 2.12 & 1.25 & 59.60 & 53.26 \\
\hline In the diet No. 3 with chicken cutlets with bran & & 5.23 & 7.28 & 10.04 & 125.36 & 3.31 & 3.77 & 1.28 & 59.89 & 53.38 \\
\hline
\end{tabular}

Table 4. Characteristics of the diet of the control and experimental groups of animals

\begin{tabular}{|c|c|c|c|c|c|c|}
\hline $\begin{array}{l}\text { Number and name of } \\
\text { animal group }\end{array}$ & Diet type & $\begin{array}{l}\text { Proteins, } \\
g\end{array}$ & $\begin{array}{c}\text { Fat, } \\
g\end{array}$ & $\begin{array}{l}\text { Carbohydrates, } \\
g\end{array}$ & $\begin{array}{c}\text { Energy } \\
\text { value, } \text { kcal }\end{array}$ & $\begin{array}{l}\text { The ratio of basic nutrients } \\
\text { in the diet P:F:C [13] }\end{array}$ \\
\hline control & Usual full-fledged diet & 5.45 & 6.54 & 9.20 & 111.87 & $1: 1.2: 1.7$ \\
\hline Experimental group №1 & $\begin{array}{l}\text { Usual full-fledged diet including } \\
\text { shortbread cake with cottage cheese }\end{array}$ & 5.42 & 7.71 & 9.33 & 122.57 & $1: 1.4: 1.7$ \\
\hline Experimental group №2 & $\begin{array}{l}\text { Usual full-fledged diet including } \\
\text { including shortbread cake with cottage } \\
\text { cheese with sea buckthorn }\end{array}$ & 5.42 & 7.66 & 9.32 & 122.07 & 1:1.4:1.7 \\
\hline Experimental group №3 & $\begin{array}{l}\text { Usual full-fledged diet including chicken } \\
\text { cutlets }\end{array}$ & 5.21 & 7.27 & 10.30 & 125.56 & 1:1.4:2.0 \\
\hline Experimental group №4 & $\begin{array}{l}\text { Usual full-fledged diet including } \\
\text { chicken cutlets with bran }\end{array}$ & 5.23 & 7.28 & 10.04 & 125.36 & 1:1.4:2.0 \\
\hline
\end{tabular}




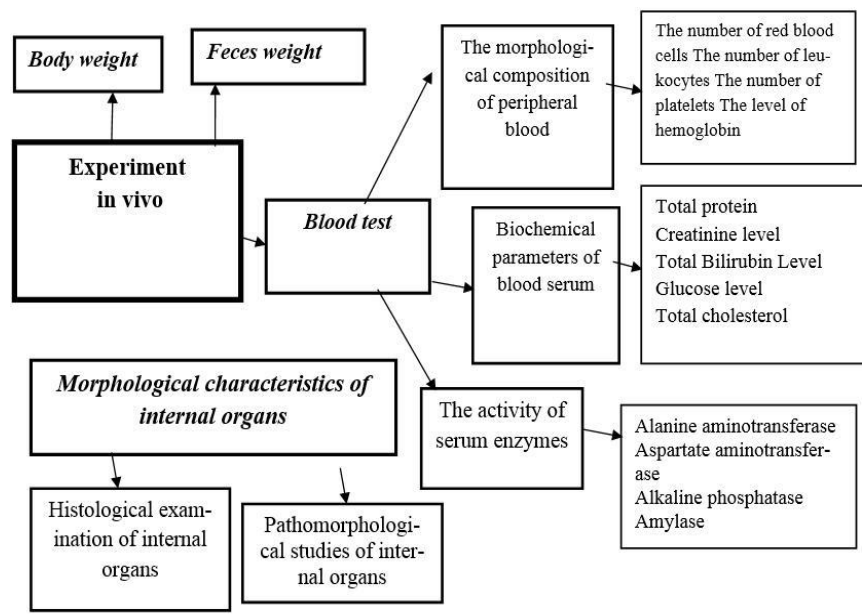

Figure 1. Scheme of the sanitary-toxicological study of rats.

In chicken cutlets with the addition of wheat bran, the total carbohydrate content has been decreased by 1.3 , with a simultaneous increase in the amount of dietary fiber. The protein content does not change. The ash content increases, which indicates that with the inclusion of wheat bran into chicken cutlets, the mineral composition of the latter improves.

\section{Animals}

Studies were conducted on 5 groups of the Wistar laboratory rats, 10 animals in each group, which differed in diet:

1. Control group of rats received a standard diet, which according to nutritional and energy values corresponded to physiological norms and the needs of the body of laboratory animals

2. Group No. 1 wherecarbohydrate part of the daily fullfledged diet $(7 \mathrm{~g})$, which came from bread $(4 \mathrm{~g})$ and cereals $(3 \mathrm{~g})$ was $100 \%$ replaced with shortbread cake with cottage cheese

3. Group No. 2 where carbohydrate part of the daily fullfledged diet ( $7 \mathrm{~g})$, which came from bread (4 g) and cereals ( $3 \mathrm{~g}$ ) was $100 \%$ replaced with shortbread cake with cottage cheese and sea buckthorn

4. Group No. 3 where chicken cutlets in an amount of $10 \mathrm{~g}$, instead of $5 \mathrm{~g}$ of meat and $0.7 \mathrm{~g}$ of meat and fish meal included in the standard diet, equal a $100 \%$ replacement of the protein part of the standard diet

5. Group No. 4 where chicken cutlets with wheat bran in an amount of $10 \mathrm{~g}$, instead of $5 \mathrm{~g}$ of meat and $0.7 \mathrm{~g}$ of meat and fish meal that are part of the standard diet, equal a $100 \%$ replacement of the protein part of the standard diet.

Groups of clinically healthy rats were formed by the method of analogues: one breed, one sex, one age, one weight.

\section{Research design}

All animal experiments were carried out on the basis of a certified vivarium of the educational and scientific-technological "Veterinary Hospital" center and laboratories of the Department of Morphology, Animal Pathology and Biology of the Vavilov Saratov State Agricultural University (Saratov, Russia).

The animals were fed for 60 days; during the entire experiment, the rats were kept in individual cages (10 animals each). Prior to the inclusion of the studied products into the diet, animals were kept in quarantine for 21 days and transferred to the diet in accordance with the research plan. The control group of rats received a standard diet, which, according to its nutritional and energy value, corresponded to the physiological norms and needs of laboratory animals (Table 2) and was previously successfully tested by us [14]. The diet of the four experimental groups of rats was partially replaced, while the total caloric value and the ratio of the main nutrients in comparison with the diet of the control group of animals did not differ (see Tables 3 and 4).

A comparative analysis of the daily diets of the experimental groups No. 1, No. 2 and the diet of the control group of animals revealed a slight decrease in protein content $(0.6 \%)$, however, at the same time, defective oatmeal and bread proteins are replaced with biologically active protein lecithin complex of cottage cheese. The increase in fat by $19.5 \%$ (shortbread cake with cottage cheese) and $17.1 \%$ (shortbread cake with cottage cheese and sea buckthorn) is associated with the inclusion of $9 \%$ fat cottage cheese and fresh sea buckthorn containing deficient arachidonic acid, which is involved in the construction of cellular membranes, and removes cholesterol from cholesterol plaques.

Analysis of micronutrient composition showed an increase in the content of riboflavin in the diet of the experimental group of rats No. 2 by $33.3 \%$ compared with the usual diet an increase in the content of tocopherol equivalent by $1.1 \%$, an increase in the content of ascorbic acid by $9.0 \%$, an increase in the content of $\beta$ carotene by 50 thousand times. From a physiological point of view, an increase in the content of the above vitamins helps to stabilize the redox processes in the body, strengthen cell membranes and increase the body's resistance to infectious diseases.

Derivatives of riboflavin as coenzymes are part of a large number of the most important redox enzymes. The unsaturated structure of $\beta$-carotene allows its molecules to adsorb light and prevent the accumulation of free radicals and ROI. Ascorbic acid and vitamin $\mathrm{E}$ (tocopherol equivalent) are actively involved in redox processes occurring in the body and, being powerful antioxidants, inhibit free radical reactions caused by both internal processes and negative environmental influences.

The third and fourth experimental groups of animals daily received respectively chicken cutlets and chicken cutlets with wheat bran in the amount of $10 \mathrm{~g}$, instead of $5 \mathrm{~g}$ of meat and $0.7 \mathrm{~g}$ of meat and fish meal included in the standard diet, which equals $100 \%$ replacement of the protein portion in a standard diet.

Analysis of the daily diet of laboratory animals shows that the $100 \%$ replacement of the protein part of the standard diet with chicken cutlets and chicken cutlets with wheat bran allowed us to increase the amount of fat in the diets by $10 \%$, carbohydrates by $10.7 \%$, and the energy value by $11 \%$. The inclusion of chicken wheat bran cutlets in the recipe contributes to an increase in animal dietary fiber by $10.3 \%$, which positively affects intestinal peristalsis, blood cholesterol, prevention of the risk of developing cardiovascular and oncological diseases, modulation of postprandial hyperglycemia and other. An increase in the vitamin PP content in the diet by $56.8 \%$ increases the niacin equivalent, and magnesium by $1.9 \%$ contributes to the normal functioning of the nervous system and a positive physiological effect on the digestive tract. An increase in iron content by $4.7 \%$ and calcium by $2.2 \%$ compared to the standard diet has a positive effect on blood composition and reduces the risk of inflammatory processes. 
After the experiment was completed, rats were euthanized by diethyl ether overdose for pathomorphological examination of the internal organs and tissues of animals.

The general scheme of sanitary-toxicological research of laboratory animals is presented in Figure 1.

The research of the effect of sea buckthorn and wheat bran in food products on the physiological status of rats was analyzed according to the general condition, the dynamics of the total mass during daily weighing, the mass of feces during daily weighing, the morphological composition of peripheral blood, biochemical parameters of blood serum, and according to the data received after morphological examination of the internal organs of the gastrointestinal tract and liver from 50 rats.

\section{Experimental technique}

During the experiment, the clinical condition and behavior of rats, motor activity, appetite, the condition of the fur of the control and four experimental groups were monitored. The parameters of the body weight of laboratory animals, the average daily mass of the collected feces of the control and four experimental groups of rats were estimated using Sartorius electronic scales (Germany), followed by the calculation of average values and their standard deviations.

\section{Blood chemistry}

Blood from rats was taken for analysis from the tail vein in a volume of 2.0-2.5 ml. The study of the clinical blood test was carried out by instrumental method on hematological analyzers: PSE 90 Vet, Biochem SA (USA production).

Glucose level was assessed using a Labsystems kit (Finland), total protein, creatinine, and total bilirubin, as well as amylase and alkaline phosphatase activity, using a Diacom-Synteko kit (Russia). The level of total cholesterol was assessed using a kit company "Lachema" (Czech Republic). The activity of alanine aminotransferase and aspartate aminotransferase was assessed using kits from Corway (Poland). Biochemical parameters and enzyme activity were assessed on a biochemical and semiautomatic analyzer FP-901 "Labsystems" (Finland).

\section{Pathomorphological study}

An autopsy was carried out with detailed recording and photographing of the material. Pathomorphological changes were studied on material from 50 euthanized animals. The autopsy of animals was carried out in the first 2 hours after euthanasia. For histological examination, samples of the internal organs of control and experimental animals were taken. To fix the pathological material, a $10 \%$ solution of neutral formalin was used.

Sections were obtained on a freezing microtome model 2515 (Reichert Wien). The prepared histological sections were stained with Ehrlich hematoxylin and eosin, followed by microscopy. The morphological structure of organs was studied in 30 ocular views of the microscope on various histological sections. A histological examination of the preparations was carried out under different magnifications with detailed logging and photographing of the studied areas.

Microphotography of histological preparations was carried out using a CANON Power Shot A460 IS camera.

\section{Statistical analysis}

Statistical analysis of the data was carried out using the licensed computer software package Statistika 10, StatSoft, Inc (Series 0411-R) and biomedical statistics methods with calculation of the average and standard error of mean. The normality of the distribution of quantitative data was checked by means of the Shapiro-Wilks test. For all indicators, including behavioral studies, with a normal data distribution, intergroup comparisons were performed with the use of the Student's t-test for independent samples at $\mathrm{P}<0.05$.

\section{Results}

During the experiment, the clinical status of rats in the control and experimental groups was monitored. Studies have shown that replacing the carbohydrate and protein components of the main daily diet of laboratory groups does not adversely affect the clinical picture and behavioral reactions of rodents.

Visual inspection of all experimental animals throughout the entire experiment showed that the hairline of the rats was flattened to the body, the presence of shine and the absence of contamination were noted. The skin was characterized by integrity, moderate humidity and elasticity, as well as the presence of a specific odor. The behavior of the animals was active.

During the two months of research, animals of all groups showed positive dynamics of body weight gain, the most pronounced weight gain was noted in the No. 1 and No. 2 experimental groups, which received a diet with partial replacement of grain and bread, respectively, on a shortbread cake with cottage cheese and shortbread cake with cottage cheese and sea buckthorn. This is due to an increase in the energy value of the daily diet of experimental animals of the first and second groups by $9.6 \%$ and $9.1 \%$, respectively. Almost identical to the control group was the increase in body weight of animals in experimental groups No. 3 and No. 4, which received a diet with partial replacement of meat and meat and fish meal with chicken cutlets and chicken cutlets with bran (Table 5).

At the same time, in subgroup No. 4 , by the end of the first and second months, a reliably high weight of feces from rats fed a diet containing chicken cutlets was recorded, respectively, 17.6+1.3 g and 19.7+1.7 g, enriched with wheat bran (Table 5).

Table 5. The dynamics of body weight and feces in rats

\begin{tabular}{|c|c|c|c|}
\hline \multirow{2}{*}{ Animal groups } & \multicolumn{3}{|c|}{ Observation periods } \\
\hline & Before experiment & 1 month & 2 months \\
\hline \multicolumn{4}{|c|}{ Dynamics of body weight, $g$} \\
\hline Control group & $166.6 \pm 26.5$ & $212.5 \pm 26.5$ & $271.6 \pm 26.5$ \\
\hline Experimental group №1 & $172.3 \pm 26.5$ & $221.4 \pm 26.5$ & $289.3 \pm 26.5$ \\
\hline Experimental group №2 & $164.5 \pm 26.5$ & $234.5 \pm 26.5$ & $293.4 \pm 26.5$ \\
\hline Experimental group №3 & $158.9 \pm 26.5$ & $211.3 \pm 26.5$ & $253.8 \pm 26.5$ \\
\hline Experimental group №4 & $167.9 \pm 26.5$ & $206.1 \pm 26.5$ & $257.9 \pm 26.5$ \\
\hline \multicolumn{4}{|c|}{ Dynamics of feces, $g$} \\
\hline Control group & $10.6 \pm 1.4$ & $11.2 \pm 1.1$ & $12.6 \pm 1.3$ \\
\hline Experimental group №1 & $12.3 \pm 1.1$ & $12.1 \pm 1.1$ & $12.8 \pm 1.4$ \\
\hline Experimental group №2 & $11.5 \pm 1.3$ & $12.1 \pm 1.2$ & $13.4 \pm 1.4$ \\
\hline Experimental group №3 & $9.9 \pm 1.8$ & $13.7 \pm 1.4$ & $14.5 \pm 1.6$ \\
\hline Experimental group №4 & $10.7 \pm 1.2$ & $17.6 \pm 1.3^{*}$ & $19.7 \pm 1.7 *$ \\
\hline
\end{tabular}

Data presented as mean with standard deviation $-\mathrm{M} \pm \mathrm{SD}$. 
Table 6. The morphological composition of rat peripheral blood

\begin{tabular}{|c|c|c|c|c|c|}
\hline \multirow{2}{*}{ Observation period } & \multicolumn{5}{|c|}{ Animal groups } \\
\hline & control & experiment №1 & experiment №2 & experiment №3 & experiment №4 \\
\hline \multicolumn{6}{|c|}{ the number of red blood cells, $10^{12} / \mathrm{I}$} \\
\hline Before experiment (background) & $7.1 \pm 0.6$ & $6.7 \pm 0.4$ & $6.9 \pm 0.8$ & $7.0 \pm 0.3$ & $6.4 \pm 0.3$ \\
\hline 1 month & $6.9 \pm 0.4$ & $7.0 \pm 0.6$ & $7.0 \pm 0.4$ & $6.6 \pm 0.6$ & $7.0 \pm 0.3$ \\
\hline 2 months & $7.0 \pm 0.3$ & $6.8 \pm 0.5$ & $6.7 \pm 0.3$ & $6.9 \pm 0.5$ & $6.8 \pm 0.6$ \\
\hline \multicolumn{6}{|c|}{ white blood cell number, $10^{9} / 1$} \\
\hline Background & $9.9 \pm 0.4$ & $9.4 \pm 0.3$ & $9.5 \pm 0.4$ & $9.7 \pm 0.5$ & $9.7 \pm 0.4$ \\
\hline 1 month & $9.6 \pm 0.8$ & $9.7 \pm 0.4$ & $9.6 \pm 0.6$ & $9.5 \pm 0.4$ & $9.9 \pm 0.3$ \\
\hline 2 months & $9.7 \pm 0.9$ & $9.8 \pm 0.4$ & $9.5 \pm 0.4$ & $9.6 \pm 0.4$ & $9.7 \pm 0.4$ \\
\hline \multicolumn{6}{|c|}{ Platelet number, $10 \%$} \\
\hline Background & $734 \pm 26$ & $728 \pm 22$ & $715 \pm 20$ & $727 \pm 19$ & $730 \pm 26$ \\
\hline 1 month & $712 \pm 28$ & $730 \pm 18$ & $712 \pm 29$ & $733 \pm 22$ & $737 \pm 23$ \\
\hline 2 months & $713 \pm 29$ & $723 \pm 21$ & $728 \pm 21$ & $712 \pm 18$ & $727 \pm 16$ \\
\hline \multicolumn{6}{|c|}{ hemoglobin level, g/l } \\
\hline Background & $98 \pm 5$ & $103 \pm 4$ & $99 \pm 8$ & $98 \pm 6$ & $99 \pm 9$ \\
\hline 1 month & $101 \pm 6$ & $99 \pm 8$ & $102 \pm 6$ & $101 \pm 5$ & $98 \pm 8$ \\
\hline 2 months & $102 \pm 3$ & $103 \pm 5$ & $103 \pm 5$ & $99 \pm 5$ & $98 \pm 9$ \\
\hline
\end{tabular}

Table 7. The activity of rat serum enzymes

\begin{tabular}{|c|c|c|c|c|c|}
\hline \multirow{2}{*}{ Observation period } & \multicolumn{5}{|c|}{ Animal groups } \\
\hline & control & experiment №1 & experiment №2 & experiment №3 & experiment №4 \\
\hline \multicolumn{6}{|c|}{ Alanine aminotransferase, $\mathrm{u} / \mathrm{l}$} \\
\hline Before experiment (background) & $92.4 \pm 5.3$ & $86.7 \pm 6.5$ & $84.7 \pm 3.4$ & $90.2 \pm 2.2$ & $91.6 \pm 6.7$ \\
\hline 1 month & $82.3 \pm 4.4$ & $89.4 \pm 5.7$ & $92.1 \pm 4.3$ & $84.4 \pm 6.7$ & $86.9 \pm 8.3$ \\
\hline 2 months & $88.4 \pm 4.3$ & $91.2 \pm 4.7$ & $85.4 \pm 8.8$ & $87.4 \pm 5.6$ & $91.1 \pm 6.7$ \\
\hline \multicolumn{6}{|c|}{ Aspartate aminotransferase, $\mathrm{u} / \mathrm{l}$} \\
\hline Background & $141.6 \pm 9.5$ & $133.8 \pm 9.8$ & $136.1 \pm 7.4$ & $137.8 \pm 6.4$ & $139.6 \pm 3.5$ \\
\hline 1 month & $138.6 \pm 8.8$ & $138.4 \pm 4.5$ & $140.2 \pm 8.2$ & $139.1 \pm 9.8$ & $137.7 \pm 5.5$ \\
\hline 2 months & $136.2 \pm 9.5$ & $140.2 \pm 4.3$ & $138.1 \pm 9.6$ & $136.6 \pm 9.4$ & $141.2 \pm 9.7$ \\
\hline \multicolumn{6}{|c|}{ Alkaline phosphatase, u/l } \\
\hline bacKground & $825.7 \pm 33.6$ & $812.6 \pm 44.2$ & $808.8 \pm 63.4$ & $844.1 \pm 34.8$ & $816.8 \pm 46.6$ \\
\hline 1 month & $844.6 \pm 43.3$ & $857.4 \pm 28.2$ & $834.4 \pm 42.3$ & $856.3 \pm 38.3$ & $855.5 \pm 38.5$ \\
\hline 2 months & $866.4 \pm 23.2$ & $823.6 \pm 36.3$ & $870.8 \pm 28.2$ & $874.7 \pm 33.2$ & $869.4 \pm 36.4$ \\
\hline \multicolumn{6}{|c|}{ Amylase, $u / I$} \\
\hline Background & $832.4 \pm 78.8$ & $812.8 \pm 54.6$ & $788.4 \pm 62.3$ & $798.8 \pm 44.5$ & $808.6 \pm 56.8$ \\
\hline 1 month & $806.7 \pm 40.4$ & $746.2 \pm 32.4$ & $765.8 \pm 54.6$ & $822.6 \pm 32.8$ & $768.8 \pm 62.7$ \\
\hline 2 months & $787.7 \pm 44.0$ & $798.3 \pm 48.9$ & $785.7 \pm 10.7$ & $762.1 \pm 56.2$ & $730.2 \pm 50.4$ \\
\hline
\end{tabular}

Table 8. Biochemical parameters of rat serum

\begin{tabular}{|c|c|c|c|c|c|}
\hline \multirow{2}{*}{ Observation period } & \multicolumn{5}{|c|}{ Animal groups } \\
\hline & control & experiment №1 & experiment №2 & experiment №3 & experiment №4 \\
\hline \multicolumn{6}{|c|}{ Total protein level, g/l } \\
\hline Before experiment (background) & $67.8+2.8$ & $64.6+2.3$ & $66.6+2.5$ & $64.4+2.7$ & $68.9+2.6$ \\
\hline 1 month & $67.9+2.4$ & $63.9+3.7$ & $69.9+1.9$ & $69.8+3.1$ & $70.2+2.2$ \\
\hline 2 months & $66.0+2.9$ & $64.2+2.8$ & $63.4+3.2$ & $68.6+2.2$ & $71.5+2.0$ \\
\hline \multicolumn{6}{|c|}{ Creatinine level, $\mu \mathrm{mol} / \mathrm{I}$} \\
\hline Background & $77.7+13.3$ & $81.2+11.5$ & $72.4+16.6$ & $68.9+13.5$ & $78.8+15.5$ \\
\hline 1 month & $69.9+18.7$ & $74.9+16.7$ & $74.9+11.8$ & $80.2+11.2$ & $76.7+16.4$ \\
\hline 2 months & $75.0+14.5$ & $68.4+18.6$ & $62.1+12.5$ & $76.4+15.7$ & $80.2+12.2$ \\
\hline \multicolumn{6}{|c|}{ The level of total bilirubin, $\mu \mathrm{mol} / / \mathrm{l}$} \\
\hline Background & $2.6+0.7$ & $2.2+0.4$ & $2.7+0.8$ & $2.5+0.7$ & $2.3+0.6$ \\
\hline 1 month & $2.4+0.6$ & $1.9+0.6$ & $0.8+0.1^{*}$ & $2.6+0.4$ & $2.7+0.8$ \\
\hline 2 months & $2.9+0.8$ & $2.3+0.7$ & $1.2+0.1^{*}$ & $2.1+0.6$ & $2.6+0.4$ \\
\hline \multicolumn{6}{|c|}{ Glucose level, $\mu \mathrm{mol} / \mathrm{l}$} \\
\hline Background & $7.2 \pm 0.4$ & $7.0 \pm 0.6$ & $7.4 \pm 0.4$ & $7.2 \pm 0.6$ & $7.3 \pm 0.5$ \\
\hline 1 month & $7.1 \pm 0.7$ & $9.2 \pm 0.6^{*}$ & $8.6 \pm 0.6$ & $7.4 \pm 0.4$ & $7.6 \pm 0.6$ \\
\hline 2 months & $7.3 \pm 0.6$ & $9.8+0.2^{*}$ & $9.6+0.4^{*}$ & $7.4 \pm 0.6$ & $7.8+0.6$ \\
\hline \multicolumn{6}{|c|}{ Total cholesterol, $\mu \mathrm{mol} / \mathrm{l}$} \\
\hline Background & $2.3 \pm 0.4$ & $2.2 \pm 0.3$ & $2.0 \pm 0.3$ & $2.1 \pm 0.2$ & $2.3 \pm 0.4$ \\
\hline 1 month & $2.2 \pm 0.3$ & $2.8 \pm 0.5$ & $2.6 \pm 0.4$ & $1.8 \pm 0.3$ & $1.5 \pm 0.3$ \\
\hline 2 months & $2.4 \pm 0.5$ & $2.6 \pm 0.4$ & $2.7 \pm 0.5$ & $1.5 \pm 0.3$ & $1.3 \pm 0.1$ \\
\hline
\end{tabular}

Data presented as mean with standard deviation $-\mathrm{M} \pm \mathrm{SD}$. 
A study of the morphological composition of the peripheral blood of rats carried out throughout the experiment, after two months of daily feeding rats with enriched with the foods, did not reveal statistically significant differences in the number of red blood cells, leukocytes, platelets and hemoglobin levels in experimental animals compared with the control group rats fed a standard diet (Table 6).

The possible toxic effects on the liver and pancreas of food additives included in the new diets of feeding experimental groups of rats were studied by analyzing the activity of alanine and aspartate aminotransferases, alkaline phosphatease and amylase. Throughout the entire two-month experiment, the results of the activity of the above enzymes in the blood serum of all experimental rat groups did not go beyond the physiological norm characteristic of this type of laboratory animals and did not significantly differ from the indicators in the control group (Table 7).

Significant changes in the level of total protein in the blood serum of experimental groups, which indicates the stability of the protein-forming function of the liver, were not revealed. Indicators of creatinine levels, as a marker of possible renal failure, did not differ from those in the control group. The level of total bilirubin in the blood serum of laboratory animals of experimental and control groups throughout the experiment remained in all animals within the physiological norm from 0.7 to $6.5 \mu \mathrm{mol} / \mathrm{l}$. At the same time, in the experimental group of rats No. 2, which received a partial replacement of carbohydrates with a shortbread cake with cottage cheese and sea buckthorn in the daily diet, from the end of the first month of observation, a significant decrease in the total bilirubin content was observed, in comparison with the control and other studied groups of laboratory animals (Table 8).

To assess the effect of the additives on carbohydrate metabolism and pancreatic function, in the two-month study of feeding experimental animals with experimental diets, the glucose in the blood serum of rats was studied.

Studies have shown that in experimental groups No. 1 and No. 2 , the level of glucose in the blood of animals, as an indicator of carbohydrate metabolism characterizing the function of the pancreas, was significantly higher than in the control group and groups No. 3 and No. 4. The glucose content in the blood serum of experimental rats of the groups No. 1 and No. 2, which additionally received a shortbread cake with cottage cheese and sea buckthorn in the daily diet, respectively, reached $9.8+0.2 \mu \mathrm{mol} / \mathrm{l}$ and 9.6+0 4 $\mu \mathrm{mol} / \mathrm{I}$. In the control group and experimental groups No. 3 and No. 4, the glucose content in the blood serum of experimental animals did not exceed the limit level of $7.8+0.6 \mu \mathrm{mol} / \mathrm{l}$. Moreover, all parameters of the glucose content in the blood serum of the studied rats did not go beyond the limits of permissible physiological fluctuations (from $7.0 \mu \mathrm{mol} / \mathrm{I}$ to $10.0 \mu \mathrm{mol} / \mathrm{l}$ ), which is typical of this type of laboratory animals (Table 8).

Studies have shown that the analyzed rations of all experimental and control groups of animals did not affect the level of serum cholesterol. The exception was the 4th experimental group of animals, which received up to $300 \mathrm{mg}$ of bran with a daily diet. The cholesterol level in the blood serum of experimental animals of this group at the end of the first month of research was $1.5+0.3 \mu \mathrm{mol} / \mathrm{l}$, and at the end of the experiment $1.3+0.1 \mu \mathrm{mol} / \mathrm{l}$, which was 1.4-1,7 times lower than the cholesterol content in animals of the control and other experimental groups (Table 8).
During the visual examination of the internal organs of experimental animals after autopsy, it was noted that the lungs are uniformly colored, light pink in color, with a fluffy consistency. The liver is not enlarged, the edges are sharp, dark cherry in color, with an elastic consistency, there are lighter areas without clear boundaries. The gall bladder is filled with yellow-green bile. The heart is round oval, the pericardium is transparent, smooth, shiny, in the cavity of the cardiac shirt there is a small amount of light yellow opalescent liquid. The kidneys are gray in color with a dense consistency, the adipose capsuleis not expressed. For histological examination, samples of the liver and small intestine were taken. To fix the pathological material used a $10 \%$ solution of neutral formalin. Slices were obtained on a freezing microtome, part of the pathological material was embedded in paraffin blocks. When staining sections, hematoxylin-eosin was used.

During histological examination of the liver in the experimental groups, an increase and preservation of the beam structure of the organ was observed (Figure 2,3). Lobules did not have clear boundaries due to poorly developed interlobular connective tissue.

Analyzing the data presented in Figures 2, 3, we should noted that the histological structure of the liver of rats of experimental animals had a more pronounced beam and capillary structure, compared with the control group.

The histological results of the study of the small intestine of the experimental groups are presented in Figures 4, 5.

According to the data obtained during the histological examination of the small intestine of the experimental groups of animals (Figure 4,5), we can conclude that the villi have the correct shape, the epithelial cover is preserved. There are small accumulations of lymphoid cells between the glands. In the small intestine of sub-experimental group No. 2, an average thickness of mucous membranes of $14 \%$ was revealed.

The substitution of the carbohydrate-containing part in the standard daily diet of control animals, for bread and cereal, with an equal weight quantity due to shortbread cake with cottage cheese and a similar product with sea buckthorn for experimental rats, led to a slight increase in the caloric content of diets. So, the caloric value of the diet of the control group of animals was 111.87 kcal per day, the caloric values of the diets of the first and second experimental groups were higher and amounted to $122.57 \mathrm{cal}$ and $122.07 \mathrm{kcal}$, respectively. Feeding with higher calorie diets for two months of the experiment contributed to a significant increase in body weight of experimental animals of the first and second groups, in comparison with the control group of rats (see Table 5).

The increased caloric values of the diets of the first and second experimental groups of animals is explained by a higher content of sand fats in cakes (19.5\% and $17.1 \%$, respectively) due to the presence of $9 \%$ fat and fresh sea buckthorn and simple sugars in the cottage cheese recipes (respectively $1.4 \%$ and $1.33 \%$ ). The faster weight gain of animals of the second group could also be facilitated by the presence of organic acids in sea buckthorn, which leads to increased animal appetite and improved metabolic processes in their body.

On the contrary, in the experimental groups of rats No. 3 and 4 , in the diet of which meat and meat and fish meal were substituted respectively with chicken cutlets and similar cutlets with wheat bran, the animals gained body weight similarly to control rodents. Moreover, in the 4th experimental group of rats, by the end of the experiment, the most insignificant increase in 
body weight was observed in comparison with other groups of animals of the experimental and control groups of animals. However, there was no significant difference in in the body weight lag compared with the control group of animals that received up to $300 \mathrm{mg}(1200 \mathrm{mg} / \mathrm{kg})$ of bran per day.

At the same time, we should note a significant difference in the average weight of feces of the 4th group of rats, which is $19.7+1.7 \mathrm{mg}$, which is 1.4-1.9 times higher than the mass of weight of feces of the other experimental and control animals (Table 5). This fact is due to the well-known so-called "healing" effect of bran on the excretory function of the intestine, associated with accelerating the formation of fecal masses and their excretion from the body due to the increased peristalsis of the latter.

A distinctive feature of the diet of the third and fourth experimental groups was a higher content of dietary fiber in the daily diet of animals compared to the control group, these indicators were respectively 1.05 and 1.11 times higher.

Pathological studies did not reveal visible changes in the internal organs of the experimental groups of rats, compared with the control group of animals. The presented characteristic of the liver is characteristic of clinically healthy animals, which allows us to conclude that the use of the studied functional ingredients has a positive effect on the clinical and physiological state of the liver.

Histological studies of the internal organs of the 4th experimental group of animals confirm the above facts, which was clearly established in the study of the small intestine. Thus, in the small intestine of experimental animals of the 4th group, an average $14 \%$ thickening of the mucous membranes was revealed, which in turn improves the digestion and absorption of the necessary nutrients from the small intestine, and further promotes faster formation and removing feces from the large intestine of the animal.

The positive effect of wheat bran was also observed in rats of the 4th experimental group and in the study of the cholesterol level in the blood serum of rodents. So, in this group of animals, in comparison with the rest of the experimental and control groups, a significant $(p<0.05)$ lowest $(1.3+0.1 \mathrm{mmol} / \mathrm{l})$ serum cholesterol content was observed, which is associated with the ability plant fibers included in the diet of experimental rats to bind cholesterol in the intestine, remove it from the body and thereby prevent penetration into the blood. At the same time, this level of cholesterol corresponded to the physiological norm for animals of this species $(1.0-2.9 \mathrm{mmol} / \mathrm{l})$.

The low level of total bilirubin in the blood serum of rats of the 2nd experimental group, amounting to $0.8+0.1 \mu \mathrm{mol} / \mathrm{l}$ at the end of the first month of research and $1.2+0.1 \mu \mathrm{mol} / \mathrm{l}$ at the end of the experiment, fell within the physiological limits of fluctuations characteristic of this type of laboratory animals and apparently was associated with a high content of $0.2 \mathrm{mg}(1.0 \mathrm{mg} / \mathrm{kg})$ of ascorbic acid in the diet of this group of animals ; the ascorbic acid entered the bloodstream and violated the confirmation of bilirubin due to oxidation of bile pigment.

The above assumption is also supported by the analysis of the morphological composition of the peripheral blood of rats of this group, where the leukocyte and hemoglobin indices were identical with the control ones. The absence of pathology associated with renal failure, which causes a decrease in total bilirubin, is also evidenced by the results of pathomorphological studies, where the condition of the kidneys and adrenal glands was identical to the condition of the internal organs of the control group of animals.

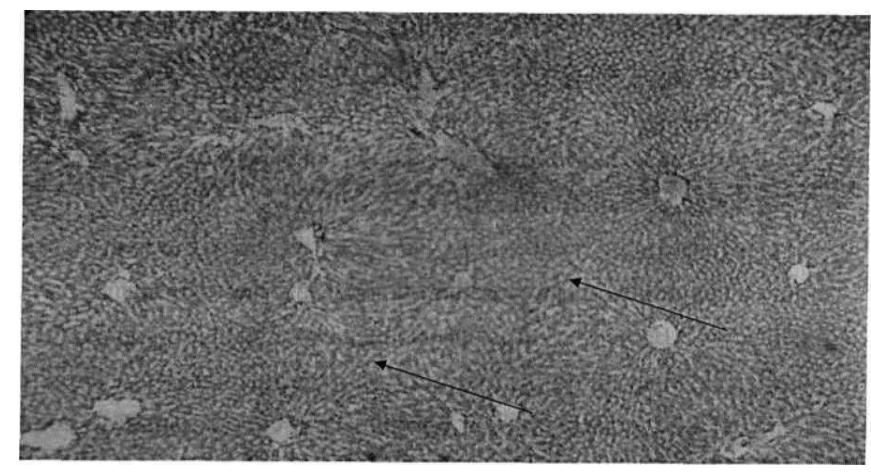

Figure 2. Liver. Experienced group No. 4.

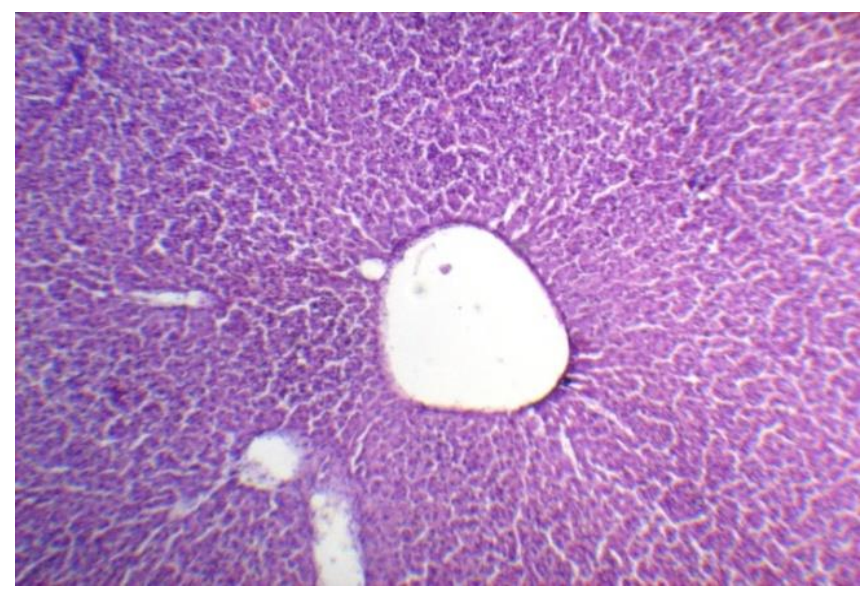

Figure 3. Liver. Experimental group No. 2.

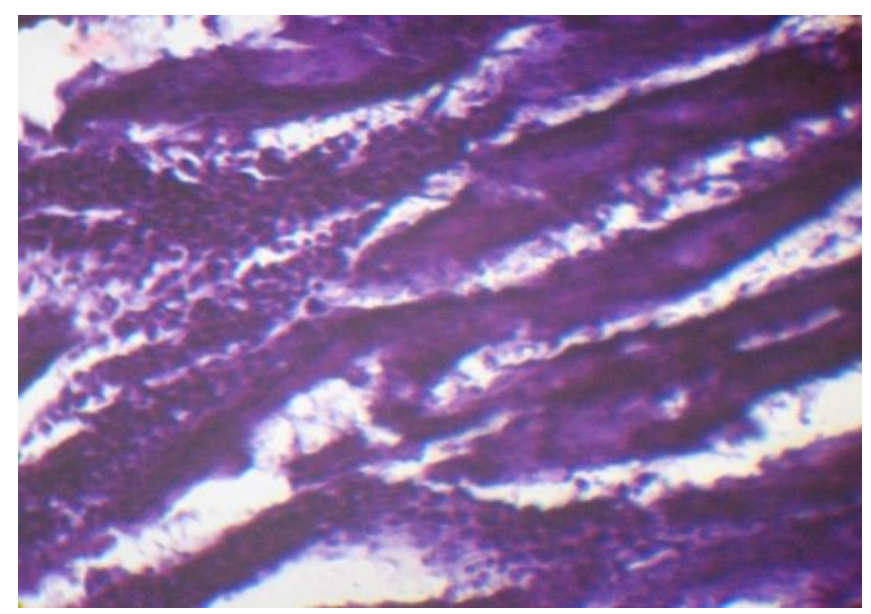

Figure 4. The small intestine. Ex-perimental group No. 2.

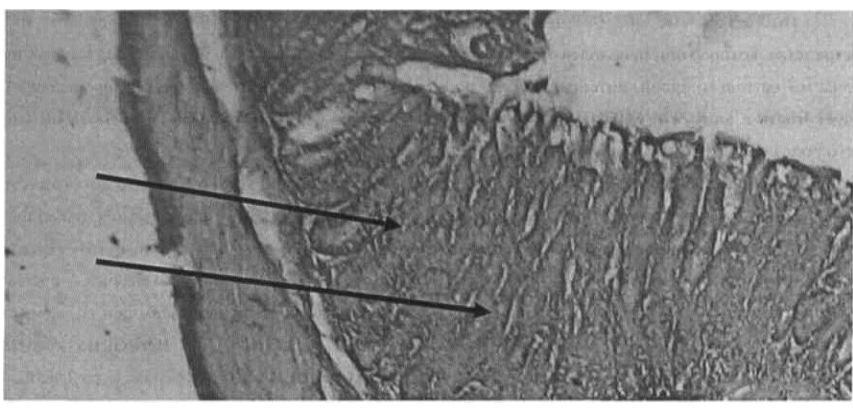

Figure 5. Small intestine. Experi-mental group No. 4 
Significantly high, yet within physiological norms, the level of glucose in the blood serum of the experimental animals of groups No. 1 and No. 2, which received a cake with cottage cheese and a cake with cottage cheese and sea buckthorn, was due to the presence of simple and easily assimilated mono- and disaccharides. It should be noted that the content of the latter at the level of $34.0 \mathrm{mg}(130 \mathrm{mg} / \mathrm{kg})$ exceeded more than a hundred times the content of simple sugars in the diet of experimental animals of the $3 r d$ and 4 th groups, while in the diet of the control group easily digestible saccharides are practically absent. In addition to that, histological studies did not reveal pathological changes in the tissues of the liver or pancreas in any of the studied experimental groups of animals, which is associated with good solubility and rapid excretion of simple sugars from animals.

\section{Discussion}

The results of this research are largely comparable with the numerous works of scientists dedicated to the therapeutic and prophylactic effect of dietary fiber on the body in various diseases. In particular, the work by Zwiki H. et al 2019 [19] points to the positive effect of dietary fiber in some forms of diabetes [15-19]. For many years, studies confirming the therapeutic effect of dietary fiber in obesity including in children and pregnant women, as well as diseases of the cardiovascular system, oncological and some others have been carried out [20-21]. It should also be noted that the beneficial effect on dietary fiber is confirmed when they are part of food products, in contrast to dietary fiber in dietary supplements, which, for example, did not have an anti-cancer effect, and sometimes, on the contrary, increased the risk of developing cancer [22].

This research paper proves the functional effect of chicken cutlets which contain wheat bran in their recipe, which is another example that confirms the need for a competent approach to the diets of a modern human, including dietary fiber in its native form.

In scientific periodicals, there are quite few research articles dedicated to the study of sea buckthorn and its physiological effects, despite the fact that this product has been used in medical practice and nutrition of Asia and Europe for many centuries [23]. However, the nutritional composition of sea buckthorn allows us to recognize this product as bio-functional, which indicates the feasibility of its use in food technology for the products with functional properties [24, 25].

The research literature contains the information on the pharmacological properties of sea buckthorn, for example, its ability to delay the insulin reaction and improve the glycemic profile [26], improve the activity of the cardiovascular and immune systems [27].

However, the studies of the nutritional profile of sea buckthorn as a physiologically functional ingredient applicable in food technology, from the point of view of evidence-based medicine, have not been reflected in scientific periodicals. The research presented by the authors showed that the capabilities of this unusually useful product in combination with cottage cheese, taking into account the hedonic preferences of a human, have a beneficial effect on the body.

According to the authors, the actual health benefits derived from the consumption of familiar foods with a given nutrient profile and proven preventive effects are of paramount importance in the daily nutrition of a modern human.

\section{Conclusion}

The result of the research was the introduction of food products with the addition of fresh sea buckthorn into the diet of experimental animals has a positive effect on the behavioral reactions of rats, enhances appetite and faster growth of animals. The addition of wheat bran to the diet of experimental animals caused a more intensive absorption of food products in the small intestine, enhanced the formation of feces, intensive emptying of the large intestine, and contributed to a decrease in the level of total cholesterol in the body of laboratory animals.

Thus, the studied products are functional, intended for the systematic use in diets by all age groups of a healthy population. The products have scientifically-based and confirmed properties, reduce the risk of gastrointestinal and liver diseases, and improve health due to the presence of functional food ingredients. For instance, native dietary fiber and PP factor vitamin were found in chicken cutlets with bran, whereas riboflavin, tocopherol equivalent and $\beta$-carotene were found in a cake with cottage cheese and sea buckthorn.

\section{Conflict of interest}

Conflict of interest is not claimed. There is no commercial interest of individuals or legal entities in the results of the study. There is no description of patent or any other (except copyright) objects in the article.

\section{Ethical approval}

Experimental studies were conducted with the permission of the Ethics Committee of the University and in accordance with EC Directive 86/609 / EEC, in accordance with the legislation of the Russian Federation regulating animal experiments in accordance with the requirements of good laboratory practice.

\section{References}

1. Lviv BV. Atomic absorption spectral analysis. Moscow, Russia: Nauka, 1966; 392 p. Russian https://search.rsl.ru/en/record/01006334415.

2. King J, Aguirre C, Pablo S. Functional properties of lupin protein isolates (lupinusalbusev Multolupa). J Food Sci 1985; 50(1): 82-87. https://doi.org/10.1111/j.1365-2621.1985.tb13282.x.

3. Dhingra $D$, Michael $M$, Rajput $H$, Patil RT. Dietary fibre in foods: a review. J Food Sci Technol 2012; 49(3): 255-266. https://doi.org/10.1007/s13197-011-0365-5.

4. Trigueros L, Peña S, Ugidos AV, Sayas-Barberá E, Pérez-Álvarez JA, Sendra E. Food ingredients as anti-obesity agents: a review. Crit Rev Food Sci Nutr 2013; 53(9): 929-942. https://doi.org/10.1080/10408398.2011.574215.

5. Halliwell B. Vitamin C: poison, prophylactic or panacea? Trends Biochem Sci 1999; 24(7): 255-259. https://doi.org/10.1016/s09680004(99)01418-8.

6. Mendelová A, Mendel L, Czako P, Mareček J. Evaluation of carotenoids, polyphenols content and antiox-idant activity in the sea buckthorn fruit juice. Potravinarstvo Slovak Journal of Food Sciences 2016; 10(1): 59-64. https://doi.org/10.5219/551.

7. Ma X, Laaksonen $\mathrm{O}$, Zheng J, Yang $\mathrm{W}$, Trépanier $\mathrm{M}$, Kallio $\mathrm{H}$, et al. Flavonol glycosides in berries of two major subspecies of sea buckthorn (Hippophaë rhamnoides L.) and influence of growth sites. Food Chem 2016; 200: 189-198. https://doi.org/10.1016/j.foodchem.2016.01.036.

8. Rop O, Ercişli S, Mlcek J, Jurikova T, Hoza I. Antioxidant and radical scavenging activities in fruits of 6 sea buckthorn (Hippophae rhamnoides L.) cultivars. Turkish Journal of Agriculture and Forestry 2014; 38(2): 224-232. https://doi.org/10.3906/tar-1304-86. 
9. Makarova AN, Simakova IV. The application of natural preservatives in the production of snack and flour confectionery products Technology and merchandising of the innovative foodstuff 2011; (4(9)): 66-69. Russian. https://www.elibrary.ru/item.asp?id=19084761.

10. Fomenko OS, Ptichkina NM. Development of technology for chopped chicken meat products with wheat bran. Meat industry 2010; (10): 1012. Russian. https://elibrary.ru/item.asp?id=19107257.

11. Makarova AN. The study of the fat component of snacks and flour confectionery during storage. PhD dissertation. Oryol, Russia, 2011; 163 p. Russian. https://www.elibrary.ru/item.asp?id=19265990.

12. Fomenko OS. Development of recipes for chicken semi-finished chicken with a complex additive. PhD dissertation. Moscow, Russia, 2011; 136 p. Russian. https://www.elibrary.ru/item.asp?id=19250482.

13. Simakova IV, Eliseev YuYu, Perkel RL, Domnitsky IYu, Terentyev AA, Strizhevskaya VN, et al. The sanitary-technological safety assessment of fat component in some types of snacks and confectionery with extended expiration date. Saratov Journal of Medical Scientific Research 2016; 12(3): 333-339. Russian. https://elibrary.ru/item.asp?id=28802361.

14. Tyshko NV, Sadykova EO. Genetically modified food products: development of safety asseessment system in Russia. Health Risk Analysis 2018; (4): 120-127. https://doi.org/10.21668/health.risk/2018.4.14.eng.

15. Sukhanov BP. Kuznetsov VD, Igoryanova NA, Zhmichenko VM. Wheat bran as a protein fortifier for cereals and their biological evaluation. In: Deposited scientific works. Natural and Accurate Science, Technology. Moscow, Russia, 1987; 1(183). Russian. https://elibrary.ru/item.asp?id=25649184.

16. Utembaeva NT. Assessment of the influence of genetically modified food sources on the reproductive system of rats and their offspring: Author. PhD dissertation. Moscow, Russia, 2011; 86 p. Russian. https://www.elibrary.ru/item.asp?id=19234726.

17. EFSA Panel on Genetically Modified Organisms (GMO), Naegeli $\mathrm{H}$, Birch AN, et al. Guidance on allergenicity assessment of genetically modified $\begin{array}{lllll}\text { plants. } & \text { EFSA }\end{array}$ https://doi.org/10.2903/i.efsa.2017.4862

18. Weber N, Halpin C, Hannah LC, Jez JM, Kough J, Parrott W. Editor's choice: Crop genome plasticity and its relevance to food and feed safety of genetically engineered breeding stacks. Plant Physiol 2012; 160(4): 1842-1853. https://doi.org/10.1104/pp.112.204271.

19. Zwickey $H$, Horgan A, Hanes D, Schiffke $H$, Moore A, Wahbeh $H$, et al. Effect of the Anti-Inflammatory Diet in People with Diabetes and PreDiabetes: A Randomized Controlled Feeding Study. J Restor Med 2019; 8(1): e20190107. https://doi.org/10.14200/jrm.2019.0107.

20. Salas-Salvadó J, Farrés X, Luque X, Narejos S, Borrell M, Basora J, et al. Effect of two doses of a mixture of soluble fibres on body weight and metabolic variables in overweight or obese patients: a randomised trial. $B r \quad J \quad N u t r \quad 2008 ; \quad 99(6): \quad$ 1380-1387. https://doi.org/10.1017/s0007114507868528.

21. Evans CEL. Dietary fibre and cardiovascular health: a review of current evidence and policy. Proc Nutr Soc 2020; 79(1): 61-67. https://doi.org/10.1017/s0029665119000673.

22. Zakrevskii VV, Liflyandsky VG. Vegetables and fruits in the prevention and treatment of cancer in the light of evidence-based medicine (part 1). Vestnik of Saint Petersburg University. Medicine 2017; 12(4): 407418. https://doi.org/10.21638/11701/spbu11.2017.409.

23. Wen P, Zhao P, Qin G, Tang S, Li B, Zhang J, et al. Genotoxicity and teratogenicity of seabuckthorn (Hippophae rhamnoides L.) berry oil. Drug Chem Toxicol 2020; 43(4): 391-397. https://doi.org/10.1080/01480545.2018.1497047.

24. Olas B. The beneficial health aspects of sea buckthorn (Elaeagnus rhamnoides (L.) A. Nelson) oil. J Ethnopharmacol 2018; 213: 183-190. https://doi.org/10.1016/j.jep.2017.11.022.

25. Shashirekha MN, Mallikarjuna SE, Rajarathnam S. Status of bioactive compounds in foods, with focus on fruits and vegetables. Crit Rev Food
Sci Nutr 2015; 55(10):

https://doi.org/10.1080/10408398.2012.692736.

26. Mortensen MW, Spagner C, Cuparencu C, Astrup A, Raben A, Dragsted LO. Sea buckthorn decreases and delays insulin response and improves glycaemic profile following a sucrose-containing berry meal: a randomised, controlled, crossover study of Danish sea buckthorn and strawberries in overweight and obese male subjects. Eur J Nutr 2018 57(8): 2827-2837. https://doi.org/10.1007/s00394-017-1550-8.

27. Olas B. The multifunctionality of berries toward blood platelets and the role of berry phenolics in cardiovascular disorders. Platelets 2017; 28(6): 540-549. https://doi.org/10.1080/09537104.2016.1235689.

\section{Authors:}

Olga S. Fomenko - PhD, Assistant Professor, Department of Food Technology, Saratov State Agrarian University named after N.I. Vavilov, Saratov, Russia. https://orcid.org/0000-0002-2700-3119.

Anastasiya N. Makarova - PhD, Assistant Professor, Department of Food Technology, Saratov State Agrarian University named after N.I. Vavilov, Saratov, Russia. https://orcid.org/0000-0001-6998-6216.

Inna V. Simakova - DSc, Professor, Department of Food Technology, Saratov State Agrarian University named after N.I. Vavilov, Saratov, Russia. https://orcid.org/0000-0003-0998-8396.

Yuriy Yu. Eliseev - DSc, Head of the Department of General Hygiene and Ecology Saratov State Medical University named after V.I. Razumovsky, Saratov, Russia. https://orcid.org/0000-0002-6507-476X.

Yuliya V. Eliseeva - PhD, Assistant Professor, Department of General Hygiene and Ecology, Saratov State Medical University named after V.I. Razumovsky, Saratov, Russia. https://orcid.org/0000-0003-4496-9107.

Elena N. Artemova - DSc, Professor, Department of Food Technology and resTaurant Management, Orel state University named after I. S. Turgenev, Orel, Russia. https://orcid.org/0000-0002-7203-4475. 